\title{
Class Concepts and Stratification Research in Slovenia
}

\author{
Anton Kramberger, University of Ljubljana \\ Miroslav Stanojević, University of Ljubljana
}

\begin{abstract}
This article deals with the concept of class and class analysis in sociological research in the last few decades in Slovenia. It reveals basic local reasons of the relative marginal role ot the analysis before and especially after 1990. First, it lists a selection of the key class and stratification studies during the communist era. Second, it describes the class and stratification studies that occured before and around the regime change (1980-1991). Third, it describes a number of stratification research studies after 1991 (to the present), with many international components. The research efforts of a few influential research groups in Slovenia that have engaged in class and stratification studies, following special approaches, are presented and commented on: Marxist tradition, a Bourdieuian approach focusing on symbolic discourse, and a structurally-based labor process approach. In the conclusion, both a substantive and methodological account of relative achievements in the field are offered.
\end{abstract}

Kewords: class analysis, stratification, Slovenia, postcommunism

This is a post-print (Version 2) of the article, which was originally published in East European Politics \& Societies. 2015. Vol. 29(3) 651-662 by SAGE Publications Ltd. The publisher's version of this article is available at http://dx.doi.org/10.1177/0888325415599201.

\section{Suggested citation:}

Kramberger, Anton, and Miroslav Stanojević. 2015. Class Concepts and Stratification Research in Slovenia. East European Politics \& Societies 29 (3):651-662. doi:

10.1177/0888325415599201. 
Living in Slovenia and writing or talking about class and class relations tends to make one uncomfortable. On a colloquial level, the term social class, translated as "družbeni razred," has always had a contested symbolic value. Traditionally, large social groups were much better grasped by the locally fully domesticated word "stan" (comparable to "Stände" in German), which pertained to the rather immobile social structure. Thus, when the term (working and social) class was introduced into the language by early modernization forces, it was always accompanied by the suspicion that it was a tool for vested interests. The historical journey of the word "class" in Slovenian public space is therefore full of misunderstandings as to what it might mean, address or judge. Even today, professionals mainly use it for quite limited purposes: either for their internal or external disputes about the achieved patterns of stratification or for an exchange of their findings with politicians and/or trade unions. In the popular media, the term, with all its possible related phrases and connotations, quickly loses its communication potential.

Why does the simple word "class", which seems to be inevitably and closely linked to the huge stratification changes in most of the modernized regions of Slovenia, cause so much misunderstanding? Our hypothesis is that, due to numerous historical reasons, various factions of old and emerging new social groups, which have always had difficulties uniting in a common pursuit of their interests, remain deeply fragmented. As a result, most social actors simply do not recognize themselves in this term.

This can be made clearer by setting out a few historical facts. Until the second half of the $20^{\text {th }}$ century, Slovenia was essentially a rural, politically dependent region. When the Habsburg monarchy was dissolved in 1918, three different stages of accelerated economic modernization ensued. They were introduced by three different states ruling the territory, and only had partial success. Slovenia's long political and economic subordination, with just a tiny layer of intelligentsia studying and working mostly abroad (mostly in capital cities of neighboring countries, such as Graz, Vienna, and Bologna), ${ }^{1}$ contributed to the fact that even after the country became independent in 1991, emotional national liberation stories were, and still are, often substituted for rational developmental histories. And so, when the first modern social class concepts entered Slovenia in the late 19th century, they were neither well understood nor elaborated by the local polity. Instead, subordinate local social hierarchies immediately started a fierce cultural struggle over the allegedly "more important" questions, such as which of the many unfulfilled national, cultural, religious, regional, occupational, or political goals should be given priority. Class and economic concerns were barely mentioned. 
Accordingly, Slovenian politics still tends to avoid the question of class as a public issue, and replaces it with other, often peculiar concepts to explain noticeable forms of unjust inequality. Slovenia's traditional cultural divide ${ }^{2}$ and distorted developmental options, where an older "imagined community" of Slovenians struggled with numerous emerging and competing identities, ${ }^{3}$ (such as ethnos, nation, statehood, and class), was unfortunately replicated after 1991. As the belief structure of traditional rural collectivist paternalism continues to challenge modern urban individualization, it rejects rational discussion about heated social problems and shuns the concept of economic class.

When debating history, class researchers in professional circles in Slovenia themselves tend to reproduce these stereotypical cultural patterns. In their more serious professional research and debates, however, they cite and follow academics from abroad. To present their efforts and achievements in a systematic way, this review proceeds in four steps. First, it lists a selection of the key class and stratification studies during the communist era (1945-1980), highlighting the outstanding role of the Institute of Sociology and Philosophy in Ljubljana for starting empirical sociological research in Slovenia in general, and for initiating stratification research in particular. Next, it describes the many interesting class and stratification studies that flourished before and during the regime change. These works (1980-1991) were increasingly concerned with social problems, while already anticipating major systemic change. Third, it discusses stratification studies from 1991 to the present. Finally, it explores several of the influential research groups currently engaged in class and stratification studies in Slovenia. In the conclusion we offer a substantive and methodological account of relative achievements in the field.

\section{Class Analysis during Tito's Regime (1945-1980)}

Yugoslav and especially Slovenian sociology (scholars from different regions tended to cooperate among themselves) differed from mainstream practices in many other communist countries in that orthodox Marxist theory was never the only foundation for discussions on class. There was of course the Yugoslav "Praxis" school (from the journal of the same name), which produced excellent work from a critical Marxist perspective already in the 1960s. And in Slovenia, a Marxist, so-called "nominal" approach made general claims about the causes of social divisions, without reliance on concrete evidence, usually through thought experiments sometimes supplemented with confirmatory case studies. Philosophical reflections on class, 
alienation and stratification processes in communist Slovenia by Pirjevec and Saksida did not move far beyond the basic conceptual level. ${ }^{4}$ Their work used the categories of orthodox Marxism and dealt with the questions of class struggle and ideology.

Non-Marxist empirical sociology based on social surveys, however, took root in Slovenia already in the late 1950s, under the influence of Western scholars visiting the country in the framework of aid for the Tito regime. In 1958, the French sociologist of leisure, Joffre Dumazedier, organized a Time Budget Conference, followed soon by Arnold Tannenbaum, who gave lectures on the sociology of work, and the American scholars Sidney Verba, Jan Triska, Jeremy Azrael, and Norman Nie, who offered lectures on citizen participation in local government. One of the first domestic works in this genre was Vojin Milić's 1961 paper comparing aggregate mobility in Yugoslavia's federal units. ${ }^{5}$ Empirical research on stratification was initiated at the Institute of Sociology and Philosophy in Ljubljana (initially established outside of the University), and only later transferred to universities proper. By the late 1960s, the Institute had put together a strong interdisciplinary team of stratification researchers with extensive international contacts. ${ }^{6}$ This group went on to produce a number of provocative comparative stratification papers on Yugoslavia and Slovenia, dealing with such topics as the role of politics in mobility regimes, ${ }^{7}$ the formation of elites, status inconsistency, social inequality among youth, and women's mobility. ${ }^{8}$ Based on the survey results, some argued that Slovenia's pre-1945 stratification order had largely remained intact despite the communist revolution. The revolution had changed ownership relations, but not the hierarchical status order or the socialization and reward systems. Precommunist "processes of intergenerational and intragenerational social mobility," they argued, "had proved surprisingly durable."9

The first large academic empirical stratification research study in Slovenia was completed in the late 1960s at the Faculty of Political Sciences using data from the Slovenian Public Opinion Survey (established in 1968). After the late 1970s, the otherwise weak impact of the Institute of Sociology on the academic stratification research vanished. During the early 1980s, traces of previous stratification studies could be found in the works of Gregor Tomc, ${ }^{10}$ and in the huge empirical project of the Institute, Quality of Life in Slovenia, which started in $1982 .{ }^{11}$ In a sign of the more engaged climate of professional as well as national rivalry (between federal units) in the late 1980s, the Slovenian Vojko Antončič challenged the hypothesis of the Serbian scholar Mladen Lazić concerning decreasing status mobility in Yugoslavia and argued that only the structural component of overall mobility was in relative 
decline (due to slower changes in occupational and industrial structure), while net (pure) mobility was not. ${ }^{12}$

In 1992, the Institute of Sociology was abolished, not for direct political reasons but because its projects were perceived to be "obsolete," "too expensive," and "unnecessary," due to the limited publications of its researchers. ${ }^{13}$ Several of its researchers moved to the Faculty of Social Sciences, where empirical sociology concerning the impending enormous social change was on the rise. New stratification studies soon came out on family life, leisure and life-style, employment and social policy, social justice, housing, and the transition from school to work. ${ }^{14}$

\section{$\underline{\text { Academic Class Analysis Anticipating Regime Change (1980-1991) }}$}

During the last decade of the communist era Slovenia became a quite complex society. Social distances grew significantly. Increases in the standard of living and available, cheap credit lines, despite inflationary spirals, allowed people real latitude in choosing a desired lifestyle. In the late 1980s, worried communist leaders sponsored a large research project called Class Composition of Yugoslav Societies, ${ }^{15}$ to gain an insight into changed behavioral and psychological patterns. Mainstream sociology was again being sponsored by a worried political elite. In 1991, before the results could be fully explored, Yugoslavia fell apart. With national tensions at a boiling point, most researchers refrained from publishing findings, fearful that professional judgments might be overloaded by daily quarrels. One publication, however, did produce a clearer picture of Slovenian social structure. Mitja Hafner-Fink found that located above the lower and middle classes (embracing approximately $60 \%$ of the population) and besides if not above even the professionals, two distinct new elite groups had emerged, with opposing views on further development - a larger group of the political elite, with a relatively low education, and a highly educated influential managerial elite. ${ }^{16}$ HafnerFink argued that most mobility channels between the lower and upper classes, except for education, were relatively blocked. Even educated managers were being promoted thanks to previous Communist Party membership.

Those findings on the latent and sometimes open tensions between the political and managerial elite were closely linked to another hot discussion of the 1980 s on a topic of concern both to the official ideology and critical sociology: the workers' self-management system. The critical sociology approach was strongly influenced by works of Croatian 
sociologist Josip Županov, who argued that self-management was a joint project of the traditional working class and the political elite aimed at limiting the power of enterprise managers, who sought to liberalize labor relations and weaken state control over the export sector. In this coalition, the political elite ensured workers' job security, regular pay (low salaries but full social protection), and the participatory workplace decision-making structures in return for acceptance of continued elite rule. ${ }^{17}$

Slovenian sociology divided in its assessment of this "great coalition" along radical left and conservative lines. Radicals argued that self-management constituted only a fictitious industrial democracy, and called for "real" worker management instead. Conservatives claimed there was too much worker participation already, that self-management was overdeveloped, with the result that companies were focusing on their social functions, as agents of social welfare, rather than on their market or business functions. Managers had become passive and companies disorganized, they complained, and argued for a power redistribution to improve the managers' autonomy.

Other debates at the time concerned the likely decline of status inconsistencies with system transformation (only self-employed artisans exhibited a durable consistent status), ${ }^{18}$ as well the effect of hyperinflation on stratification outcomes, with Svetlik and Bernik showing that it was having fewer serious consequences than was the case for the USA in the late 1970s, chiefly due to Slovenia's lower standard of living and greater egalitarianism. ${ }^{19}$

\section{$\underline{\text { Rich Yet Fragmented Stratification Research After } 1991}$}

In the 1990s class-centered speech largely disappeared from both public and academic discourse. It was replaced by a softened Weberian notion of market-driven stratification, yielding new status groups and heterogeneous life-style groups. Sociologists continued their research on inequality, but with different terminology, altogether dispensing with Marxist concepts from the past. In the unpleasant war atmosphere, Slovenian sociologists tended to avoid topics of nationality concerning former Yugoslav republics and the wider Balkan region. Support for renewed research into class issues, however, came from the labor movement. In the early 1990s labor was rapidly empowered during a wave of mass strikes provoked by early "wild privatization" (managerial efforts to take over state firms) and by government intentions to implement a wage freeze. 
The strength of the labor movement led to the conclusion of a series of competitive social pacts which, offering workers employment security and the continuation of beneficial welfare mechanisms in exchange for hard, intensive work, underpinned the relative economic success of the economy until $2004 .^{20}$ Slovenia found itself heralded abroad as a beacon of inclusive neocorporatism. ${ }^{21}$ But soon after the country joined the European Union (2004) and the European Monetary Union (2007), those agreements lost impetus. Competiveness based on work intensification was exhausted. One study found that Slovenia in the 2000s had the second highest percentage of individuals with long-lasting illness in the EU, just below Finland. $^{22}$ The negative effects of this competitive strategy manifested themselves chiefly in labor-intensive manufacturing industries, which lagged behind the advanced markets in terms of technological level and business efficiency, problems that came to a head in the crisis of $2008 .^{23}$

On the other side, new structural opportunities (pluralist party democracy, denationalization, privatization, accession to the EU and inflows of financial incentives) led to new upper classes composed of political leaders and party heads, huge land and equity owners, major enterprise owners, corporate heads and board members, supervisory board members of state agencies, funds, and foundations, and eventually also new mass media owners and leaders. As media discourse focused on successful individuals, academic research chiefly turned to structural explanations, justifications or critiques of the new rich, analyses of their coalitions, and inquiry into continued low income inequality. The ability of the political and economic elite to move far ahead of the others, again with the traditional domination of the political fraction, has been excellently described by Ali Žerdin using the (elite) network theory approach. ${ }^{24}$

Slovenian researchers became increasingly involved in large international projects, such as the International Social Justice Project, with special stratification studies in 1992 , 1998 and 2009, and the cross-national elite study designed by Donald Treiman and Iván Szelényi. ${ }^{25}$ Some studies concerned long-term stratification trends in Slovenia, with class conceptualized through occupation rather than property relations, using CASMIN definitions. For example, using Blau-Duncan models and pooled data for the 1920-2000 period, Ganzeboom, Kramberger, and Niewbeerta demonstrated that Slovenian destratification policy during socialism had been relatively successful in terms of educational achievement, and less so for occupational achievement. ${ }^{26}$ Other work on stratification concerned cultural and class differentiation in consumption patterns, living conditions, and education. ${ }^{27}$ Important 
stratification works came from Sonja Drobnič, one of the best known stratification researchers from Slovenia, who has done important work on inequality and family and career patterns and trends in Slovenia. ${ }^{28}$

\section{Theorizing on Class and Stratification after 1991}

The social reality of market transformation after 1991 turned the attention of researchers to emerging winners and losers (the latter including flexibilized laborers, migrant workers, unemployed youth, and the poorly educated ). Gender inequality also became a major concern, in the media too, focused on the workplace and education, and even more on questions of work-family balance. Soon, however, a set of more fundamental questions emerged about the path Slovenia had taken, and its consequences. As the share of the industrial workforce slipped to $20-25 \%$, with miscellaneous and often precarious service labor approaching $70 \%$, questions about continually growing inequality and even the future of work took center stage. When the crisis in 2008 hit Slovenia - with a delay, but all the more powerfully - many began re-examining the entire postcommunist social formation. But how to think about it? Most post-1991 research concentrated more on methodology than theory. Theorizing about systemic inequality had been discouraged by both the left and right political coalitions and the mass media, all of whom essentially advocated inequality by their support for the strengthening of market reforms. For a new generation of researchers, surface description of atomized individuals and growing income inequality on the one hand, or the invoking of Slovenia's comparatively low Gini coefficient on the other, no longer sufficed. They sought a more comprehensive picture that could only be obtained by developing a theoretically informed class conceptualization.

We can identify four different contemporary approaches to class thinking: a political activist approach inspired by Marx, Gramsci and world-system theory; a symbolic discourse approach taking its lead from Bourdieu; an empirical stratification approach based on survey testing of a loosely defined modernization thesis; and a socio-economic structural approach following the literature on globalization's impact on the state and industrial relations. Let's look briefly at all of these in turn.

A group of class-oriented scholars with preferences for macro structuralist theorizing is gathering around Rastko Močnik at the University of Ljubljana. This group, which includes younger scholars such as Primož Krašovec, Lev Centrih, Jernej Kosi, Maja Breznik, and 
Lidija Radojević, has reintroduced left class-struggle concepts into public and professional debates. It produces sharp Althusserian-type structuralist critiques of hegemonic patterns including inequality triggered by neoliberal social transformation and quiescent intellectuals. It sees global capitalism as the driving force of contemporary social changes, and charges the older generation of scholars of favoring a nationalist over a class perspective. ${ }^{29}$

The symbolic discourse school takes its lead from semiotics and Bourdieu's culturally based reframing of class into a more complex structural theory of group-making, symbolic power and domination (with the concepts of social space, habitus, and symbolic violence substituted for the older concepts of class structure, consciousness, and ideology, respectively). Its leader, Drago Rotar from the University of Primorska, carried out a semiotic analysis of Slovenian painting already in the 1960s, and in the 1980s initiated an acclaimed series of translations of classic French sociological texts, bringing Braudel, Foucault, Bourdieu, Levy-Strauss, Barthes and others to a new generation of Slovenian readers. In the 2000s, together with younger scholars such as Taja Kramberger, Iztok Osojnik, and Sabina Mihelj, he introduced a program of historical anthropology studies. Combining core concepts of post-structuralism with carefully designed case studies from Slovenia, this group critically investigates such questions as provincial mentality, collective memory, corporate and professional class closure, and hierarchical middle class inbreeding. ${ }^{30}$ Recent objects of inquiry include historical currents of cultural, symbolic exchanges between Slovenia and Central Europe, Austria, Germany, the Balkans, and France.

The third major group in the country is less theoretically oriented and deals empirically and inductively with stratification, embracing short-term horizons. Main figures in this group include Niko Toš, a prominent survey methodologist already in the 1960s, as well as Brina Malnar, Samo Uhan, Mitja Hafner-Fink, Slavko Kurdija, Ivan Bernik, and Vlado Miheljak. Mining public opinion surveys that have been conducted yearly since 1968, and engaged in several European-wide stratification projects, they have come up with some surprisingly fresh findings. Bernik coined the term "by-modern society" to describe Slovenia in the $1980 \mathrm{~s}$, referring to its role as a semi-peripheral export-oriented country mediating between the core and periphery, without developing the attributes of western modernity. ${ }^{31}$ More recently, Karl H. Müller and Niko Toš developed an interesting methodological approach to uncover multidimensionally defined new social classes in Slovenia, following Beck's ideas of risk society and core-periphery relations ${ }^{32}$. 
Finally, the group that discusses class in Slovenia from a perspective of the labor process and "varieties of capitalism" includes the present authors. Our research has tried to connect work process issues (wages and participation) and industrial relations themes (trade unions, neocorporatism, collective bargaining and social dialogue) with macro-stratification and labor market segmentation. ${ }^{33}$ These studies note changes in the stratification pattern due to a profound weakening of social dialogue in the aftermath of the recent crisis. Both right and left coalitions today take a clear neoliberal orientation, quite different from the neocorporatist logic established in the 1990s. The outcomes of these changes remain unpredictable, as despite recent setbacks, organized labor still retains significant strength.

That there are such disparate approaches may also be due to the cultural factors that divide the researchers. As in other small, historically subordinate European nations, the assessment of Slovenia's history is rife with disagreement. How to interpret past elites' comportment during civil and military interactions with Germany, Austria, Italy, the Vatican, Hungary, other Balkan nations, Turkey and Russia, and to a lesser extent with France and the UK? Attitudes on these issues often derive not from rational analysis but from family ancestry or a sense of loyalty to one position or another. Even professionals working on stratification research cannot agree upon any key historical event, and nor can they agree on the main causes and drivers of past and present inequality. Researchers from the different traditions discussed here often see themselves locked into different cultural camps. Despite, or because, it is such a small country, they rarely discuss matters among themselves ${ }^{34}$. All the approaches discussed above, not to mention the interesting though limited EUROSTAT studies on Slovenian and European inequality (which separate groups by age, not class), provide elements of a fuller understanding of contemporary class stratification, but a clear and full picture is still quite elusive.

\section{Concluding Remarks}

In public discussion there seem to be three chief objections to class analysis: a traditional objection, a modernization-based one, and an anarcho-communitarian objection. The traditional critique is the most widespread. It claims that Slovenians, now and in the past, have basically always been farmers and peasants at heart, with a common, obedient, religious (Catholic) comportment, and a stereotypical national culture. According to this view, the idea 
of class divisions is a foreign concept with false origins in the communist era and its exaggerated Marxist doctrines.

The modernization-oriented objection accepts that the working class might be a real subject of interest in the neoliberal era, especially in protest movements, corporatist bargaining, media debates, and social science. But society is exceedingly complex today, and no common interest representation is possible. Divided by trade, trade unions lack practical experience of common class action, and the concept itself thus lacks theoretical coherence.

The third, anarchic critique puts forth the radical, anthropological claim that class, like other classification terms of the societal order, has no real meaning. Such concepts are the inventions of elites, used to legitimize existing social hierarchies and maintain domination over other social groups. Leaders at all levels thus furiously deny the role of anarchic behavior and thinking in public space, claiming that challenging social hierarchies can only "spoil everything that really counts."

Until 1990, the main body of Slovenian empirical research on class and stratification belonged at best to what Ganzeboom et al. call the first generation of stratification research, ${ }^{35}$ using univariate or bivariate (aggregate) tables along with extensive comments. Only a limited number of internationally comparable empirical stratification studies had yet been completed in Slovenia. If, in 1992, Sørensen could demand of Western stratification scholars: "More matter, with less art!" ${ }^{36}$ - on the grounds that authors avoided making comments on social problems by applying too much math to quite poor data - one might rebuke this first generation of Slovenian research with the opposite charge: "There is too much matter, with too little art."

Today, with the exception of a small number of researchers, the focus on class inquiry, in either its nominal or numerical representation, is vanishing from both political discourse and the research agenda. A common overall picture of changes in the class structure and changing patterns of inequality, before and especially after 1991, is not only missing, but does not seem to be desired. Little suggests the current fragmented state of stratification research in Slovenia will change anytime soon. Indeed, at present there are no special courses on theoretical or empirical (model-based) stratification and mobility research at the graduate or postgraduate levels. Bologna reforms in higher education, aimed at providing students with attractive courses rather than ones with civic relevancy, or evidence-based interrogations of social problems, will not rectify the situation. Budget cuts on education introduced in 2012 are likely only to make things worse. 
(Last version, after peer review and before publishing in the EEPS -

East European Politic and Societies, ISSN 0888-3254, Aug. 2015, vol. 29, no. 3, str. 651-662)

\section{AUTHORS' BIO}

Anton Kramberger is associate professor of social science research methods, stratification research and sociology of labor markets at the Faculty of Social Sciences, University of Ljubljana.

Miroslav Stanojević is professor of industrial relations at the Faculty of Social Sciences, University of Ljubljana. 


\section{$\underline{\text { Notes }}$}

1 Alojz Cindrič, "Socialni izvor študentov s Kranjske na dunajski univerzi 180401918," in Alojz Cindrič, ed., Včeraj in danes: jubilejni zbornik socioloških razprav ob 50-letnici Oddelka za sociologijo, Filozofske fakultete Univerze v Ljubljani: 1960ロ2010, 231-259. (Ljubljana: Filozofska fakulteta).

2 Jasna Fischer, "Delavska izobraževalna društva in začetki delavskega gibanja v Ljubljani," Zgodovinski časopis XXVII 1प2(1973): $21 \square 36$.

3 Dragotin Gustinčič, Das nationale Problem der Slowenen (Moskow, 1933 - manuscript); Edvard Kardelj, Razvoj slovenskega narodnega vprašanja (Ljubljana: Naša založba); Tine Hribar, Slovenska državnost (Ljubljana: Cankarjeva založba, 1989).

${ }^{4}$ Dušan Pirjevec, "Pripombe k vprašanju o razslojenosti sodobne slovenske družbe," (orig: 1965); and Stane Saksida, "Socialna stratifikacija v Jugoslaviji" (orig: 1967), in Družboslovne razprave 30031(1999).

5 Vojin Milić (1961): Osvrt na društvenu pokretljivost u Jugoslaviji / Statistička revija 3ロ4(1961): 1840235.

${ }^{6}$ Marjan Kroflič, M. (1999): "Prispevek v mozaik zgodovine Instituta za sociologijo in filozofijo pri Univerzi v Ljubljani ob njegovem jubileju,” Družboslovne razprave 30ロ31(1999): $17 \square 34$.

7 Kostimir Momirović, Žiga Knap, "Some models of social mobility," in Stane Saksida et al. (1974): 1190134.

8 These papers appear in Stane Saksida et al., ed., Some Yugoslav Papers Presented to the VIII ISA Congress Toronto (Ljubljana: Institute of Sociology and Philosophy, 1974).

9 Ibid., p. 256.

${ }^{10}$ Gregor Tomc, "Social Equality and Inequality in Yugoslavia," in A Reader on Comparative Social Stratification, 650104 (Tokyo: Ishikawa \& Kawasaki, 1983).

${ }^{11}$ An exhaustive bibliography is found in Nevenka Černigoj-Sadar, Quality of Life Studies - Bibliography 19831992 (Ljubljana: Center for Social Welfare, Faculty of Social Sciences, University of Ljubljana, 1992).

${ }^{12}$ Vojko A. Antončič, "Dekomponiranje mobilnostne matrike (Decomposition of a mobility matrix)," Metodološki zvezki 5(1989): 1000111; Mladen Lazić, U susret zatvorenom društvu (Zagreb: Naprijed, 1987).

${ }^{13}$ Personal communication with the last director of the Institute.

${ }^{14}$ Katja Boh, "European Family Life Patterns - a Reappraisal," in K. Boh et al., eds., Changing Family Patterns of European Family Life: A Comparative Analysis of 14 European Countries (London: Routledge, 1989); Nevenka Černigoj-Sadar, "The Other Side of Employed Parents' Life in Slovenia," in Marriage and Family Review 1-2 (1989); Nevenka Černigoj-Sadar, "Leisure and Informal Work in Slovenia," in in S. Parker and A. Tomlinson, eds., Labour, Leisure, and Lifestyles: International Comparisons (Leisure Studies Association England, 1989); Ivan Svetlik, "From Welfare State to Welfare Society: Changing the Balance Between Gainful Employment and Informal Work in Yugoslavia," in A. Evers, H. Nowotny, H. Wintersberger, eds., The Changing Face of Welfare, (London: Gower Press, 1986); Vojko A. Antončič, Veljko Rus, "Conceptions and Perceptions of Justice in Yugoslavia," in Jacek Szmatka, ed., Society in Transition, (Amsterdam: Elsevier, 1991); Srna Mandič, "Housing Provision in Yugoslavia: Roles of the State, Market and Informal sectors," in W. van Vliet, J. van Weesep, eds., Government and Housing - Development in Seven Countries (London: Sage, 1990); Veljko Rus, Sonja Drobnič, "The Transition from School to Work," in P. Grootings, ed., Youth, Education and Work in Europe, (London: Routledge, 1989).

${ }^{15}$ Niko Toš and Peter Jambrek, Class Composition of the Contemporary Yugoslav Society (Ljubljana: Public Opinion Research Centre, University of Ljubljana, 1987).

${ }^{16}$ Mitja Hafner -Fink, "Uporaba metod razvrščanja v skupine pri proučevanju socialne strukture - socialna struktura sodobne slovenske družbe," in: Antončič et al., ed. 1988, Stratifikacijske analize sodobnih družb : Slovensko sociološko srečanje 88 (Ljubljana: MC CK ZKS: Slovensko sociološko društvo: RSS): 7૫ 37. ${ }^{17}$ Josip Županov, "Samoupravni socializem - konec neke utopije”, in Študijski dnevi 1989, Socializem in demokracija (Ljubljana: FSPN, 1989): 106.

18 For an overview, see Ivan Bernik, "Slojevitost jugoslovanske družbe," in Antončič et al. (ed., 1988): $207 \square 231$.

19 Ivan Svetlik and Ivan Bernik, "Socialne posledice inflacije," Družboslovne razprave 6 (1989): 71081 
Miroslav Stanojević, Alenka Krašovec, "Slovenia: Social Pacts and Political Exchange," in Social Pacts in Europe, ed. Sabina Avdagic, Martin Rhodes, and Jelle Visser, 2320256 (Oxford: Oxford University Press, 2011).

$21 \quad$ Dorothee Bohle and Bela Greskovits, Capitalist Diversity on Europe's Periphery (Ithaca: Cornell University Press, 2012).

22 Anthony B. Atkinson and Eric Marlier, Income and living conditions in Europe (Luxembourg: Publications Office of the European Union, 2011), 204.

23 Gorazd Kovačič, "Industrijska politika v Republiki Sloveniji - (D) Predelovalne dejavnosti," Delovni zvezek, 5(2001) (Ljubljana: UMAR); Arjana Brezigar, "On the Possibility of Negative Effects of EU Entry on Output, Employment, Wages and Inflation in Slovenia," IMAD Working Paper 5(2004) (University of Siena: IMAD).

$24 \quad$ Ali Žerdin, Omrežje moči: epicentri slovenske politične in gospodarske elite (Ljubljana: Mladinska knjiga, 2012).

$25 \quad$ See Anton Kramberger and Vasja Vehovar, "Regime change and elite dynamics in Slovenia during the 1990s: What can the elite reproduction rates tell us?", in Družboslovne razprave 32/33(2000): 1430180. ${ }^{26}$ Harry B. G. Ganzeboom, Anton Kramberger, and Paul Nieuw Beerta, "The parental effect on educational and occupational attainment in Slovenia during the 20th century," Družboslovne razprave 32/33(2000):

$9 \square 54 . K r a m b e r g e r$ also found sound double differences in mobility regimes during and after socialism with regard to gender and sector effects, respectively; see Anton Kramberger, Poklici, trg dela in politika (Ljubljana: Faculty of Social Sciences, University of Ljubljana, 2000).

${ }^{27}$ Breda Luthar et al., Medijska potrošnja, razred in kulturna stratifikacija (končno raziskovalno poročilo s sumarnikom) (Ljubljana: Faculty of Social Sciences, 2011); Jana Javornik and Brina Malnar, "Perceptions of living conditions," Social overview 1(2000): 4856; Srna Mandič and Andreja Cirman, "Housing Conditions and Their Structural Determinants: Comparisons within the Enlarged EU," Urban Studies 49(2012): 7770793; Angelca Ivančič, "Education and shifts between labour-market states in the transition from the socialist to the market economy: The Slovenian case," European Sociological Review 4(2000): 4030425.

${ }^{28}$ Sonja Drobnič and Nevenka Černigoj-Sadar, "Who marries whom in Slovenia?" in Hans-Peter Blossfeld, A. Timm, eds., European studies of population, vol. 12., 2950314 (Dordrecht; Boston; London: Kluwer Academic, 2003).

${ }^{29}$ Josip R. Močnik, "Delovni razredi v sodobnem kapitalizmu," in Postfordizem : razprave o sodobnem kapitalizmu (Zbirka Politike), ed. Gal Kirn, $149 \square 202$ (Ljubljana: Mirovni inštitut, 2010).

${ }^{30}$ Taja Kramberger, Sabina Mihelj, and Drago B. Rotar, "Representations of the nation and of the other in the Slovenian periodical press before and after 1991, “ in Orlin Spassov, ed., Quality Press in Southeast Europe (Sofia: Südosteuropäisches Medienzentrum, 2004).

${ }^{31}$ Ivan Bernik, "Current research on social stratification in Yugoslavia: some generalisations and comments," ÖZS, Österr. Z. Soziol. 2 (1990): 17ロ25; Ivan Bernik, "Politics and society in postsocialism," International journal of sociology 2/3 (1994): 45060; Ivan Bernik and Brina Malnar, "Notions of distributive justice and attitudes to the state's role in post-socialist societies," in Soziale Ungleichheit in der erweiterten Europäischen Union (Hamburg: Krämer, Beiträge zur Osteuropaforschung, 2008).

${ }^{32}$ Karl H. Müller and Niko Toš, "The organization of modern societies: Core-periphery or vertically stratified?" Teorija in praksa 3 (2012): $566 \square 588$.

${ }^{33}$ Miroslav Stanojević, "Production coalitions in Slovenian companies: Employee participation in nonparticipative organizations?" Journal of East European Management Studies 3 (2004): 2250242; Stephen Crowley and Miroslav Stanojević, "Varieties of Capitalism, Power Resources, and Historical Legacies:

Explaining the Slovenian Exception.” Politics and Society 39:2 2 (2011): 268ם295; Anton Kramberger, "Social and environmental implications of re-emergent labour market segmentation in Slovenia," Yearbook 2009 of the Institute for Advanced Studies on Science, Technology and Society (München; Wien: Profil, 2010): $225 \square 273$.

${ }^{34}$ A rare exception would be a discussion on elite (dis-)continuity after 1990, see Frane Adam, Matevž Tomšič, "Elite (re)configuration and politico-economic performance in post-socialist countries," Europe-Asia studies 3 (2002): $435 \square 454$. 
(Last version, after peer review and before publishing in the EEPS -

East European Politic and Societies, ISSN 0888-3254, Aug. 2015, vol. 29, no. 3, str. 651-662)

${ }^{35}$ Harry B. G. Ganzeboom, Donald J. Treiman, Walt C. Ultee, “Comparative Intergenerational stratification Research: Three Generations and Beyond," Annual Review of Sociology 17(1991): $277 \square 302$.

${ }^{36}$ Jesper B. Sørensen, “'More matter, with less art': A rejoinder to Erikson and Goldthorpe,” European Sociological Review 3(1992): 307ロ310. 